\title{
Economic History Association
}

The Economic Theory of Sharecropping in Early Modern France Author(s): Philip T. Hoffman

Source: The Journal of Economic History, Vol. 44, No. 2, The Tasks of Economic History (Jun., 1984), pp. 309-319

Published by: Cambridge University Press on behalf of the Economic History Association

Stable URL: http://www.jstor.org/stable/2120708

Accessed: 17-03-2016 23:47 UTC

Your use of the JSTOR archive indicates your acceptance of the Terms \& Conditions of Use, available at http://www.jstor.org/page/ info/about/policies/terms.jsp

JSTOR is a not-for-profit service that helps scholars, researchers, and students discover, use, and build upon a wide range of content in a trusted digital archive. We use information technology and tools to increase productivity and facilitate new forms of scholarship. For more information about JSTOR, please contact support@jstor.org. 


\title{
The Economic Theory of Sharecropping in Early Modern France
}

\author{
Philip T. HofFMAN
}

This paper uses a simple economic model of contract choice to explain the growth of sharecropping in sixteenth- and seventeenth-century France-a topic that figures in much of the social and economic history of the period. The theory turns out to fit both qualitative and quantitative evidence, and although the results are as yet only preliminary, the theory does provide a better account of the spread of sharecropping than the explanations upon which early modern historians have tended to rely.

RETWEEN the close of the Middle Ages and roughly 1700 the B French countryside witnessed a dramatic expansion of sharecropping. Little known in most regions of France in medieval times, agricultural sharecropping, to quote Marc Bloch, "showed a sudden increase" in the sixteenth and seventeenth centuries, just as it had earlier in northern Italy. For Bloch and historians ever since, the spread of sharecropping was part of a far larger process which saw peasants fall into debt and then lose their land to nobles, royal officers, city dwellers (bourgeois), and other privileged persons. This enormous transfer of property-Bloch termed it "the most decisive event of French social history" - stripped many a peasant of his property and reduced him to the status of a poor "sharecropper, often working what had once been his own land, which had been sold to some noble or rich bourgeois."1

Because of its links with the wholesale loss of peasant land, most French historians associate sharecropping with rural poverty and increasing social stratification in the countryside. They also blame it for the stagnation of the French rural economy. Cut off from cash markets and lacking any capital, the French sharecropper (so the argument goes) would simply not improve the land he worked. His landlord was equally unlikely to do so, either because such investments returned him too little or because he seemed less interested in commercial agriculture than in consuming the produce from his land and in relishing the status

Journal of Economic History, Vol. XLIV, No. 2 (June 1984). (C) The Economic History Association. All rights reserved. ISSN 0022-0507.

The author is Assistant Professor of History at the California Institute of Technology, Pasadena, California 91125.

${ }^{1}$ Marc Bloch, French Rural History, trans. Janet Sondheimer (Berkeley, 1970), pp. 125, 146-48; George Duby et al., Histoire de la France rurale, vol. 2: L'âge classique (Paris, 1975), pp. 230-31, 264. Perhaps the best local study of sharecropping in France is Louis Merle's La métairie et l'évolution agraire de la Gâtine poitevine de la fin du Moyen Age à la Revolution (Paris, 1958). In the area Merle studied, share contracts rose from less than the 5 percent of the agricultural contracts in the 1580 s to over 90 percent one century later. 
that ownership of property conferred. In addition, the draconian terms of most sharecropping contracts appeared to stifle any initiative. They dictated in great detail what a sharecropper was to do and thus, it is claimed, strangled individual initiative by tenants. ${ }^{2}$

This picture of sharecropping and of its consequences leaves something to be desired. That sharecropping grew more common in the sixteenth and seventeenth centuries and that its growth paralleled the increasing impoverishment of the French peasantry is undeniable. But it is not at all clear why anyone adopted sharecropping in the first place, nor why its spread was linked to the impoverishment of the peasantry. And, as we shall see, both contemporary attitudes and the modern theory of share contracts cast grave doubt upon the belief that sharecropping hindered economic growth in the countryside.

Let us first consider how historians have explained the adoption of sharecropping. For Marc Bloch, sharecropping suited poorer tenants, who lacked capital. It was also "preferred by landlords of the petty bourgeois type." Such owners (so Bloch argued) favored sharecropping because their estates were too meager to attract cash-paying tenants and because share leases provided produce for the cellar and deference for the ego. ${ }^{3}$ Bloch's explanation, though, does not fit the facts. According to the most thorough local investigation of sharecropping-Louis Merle's study of the Gâtine poitevine-it was not the petty bourgeoisie but the nobility who first leased farms on shares, and evidence from another region, the Lyonnais, also runs counter to Bloch. ${ }^{4}$ There, petty bourgeois landlords showed no sign of preferring share contracts, and while poorer tenants might have displayed an inclination toward cropping, the difference was so small that it could easily have been the result of chance (Table 1). ${ }^{5}$

The factors that early modern historians usually invoke to make sense of agricultural change-inflation, population pressure, and seignorial dues-also fail to account for the spread of sharecropping. Sharecropping flourished both during the inflation of the sixteenth century and

\footnotetext{
${ }^{2}$ Bloch, History, pp. 147-48; Duby et al., Histoire, vol. 2, pp. 123, 130-31, 230-31; Robert Forster, "Obstacles to Agricultural Growth in Eighteenth-Century France," American Historical Review, 75, pt. 2 (1970), 1604-5; Merle, La métairie, p. 203. The question of agricultural tenure-in particular, the failure to develop wage labor-also figures prominently in the "Brenner debate" that has enlivened the pages of Past and Present. For this, see The Brenner Debate: Agrarian Class Structure and Economic Development in Pre-Industrial Europe, ed. T. H. Ashton and C. H. E. Philpin (Cambridge, forthcoming).

${ }^{3}$ Bloch, History, pp. 146, 148.

${ }^{4}$ Merle, La métairie, p. 202.

${ }^{5}$ Admittedly, we have a small sample here, but the evidence is still unlikely to be a statistical fluke. One might worry about what would happen if the sample underrepresented one of the types of contracts-say labor contracts, which did not occur as frequently as tenancy contracts in the notarial registers. Fortunately we can put this worry to rest. Even if labor contracts were underrepresented in the sample, it would not disturb our logit coefficients (other than the constant), and hence it would not affect our conclusions.
} 
TABLE 1

LOGIT ANALYSIS OF SHARE AND NONSHARE CONTRACTS

\begin{tabular}{lcc}
\hline \multicolumn{1}{c}{ Variable } & \multicolumn{1}{c}{ Coefficient } & t-statistic \\
\hline Constant & -0.786 & -1.40 \\
PB (1 for Petty-Bourgeois Landlords, & -0.015 & -1.68 \\
$\quad$ zero otherwise) & & \\
POOR (1 for Poorer Tenants, zero & 0.753 & 1.26 \\
$\quad$ otherwise) & 83 cases & \\
N & 11.51 (3 degrees of freedom) & \\
Likelihood ratio statistic &
\end{tabular}

Note: Petty bourgeois landlords include artisans, merchants (except for marchands bourgeois), notaries, and minor officers. Poorer tenants include laboureurs and those for whom no occupation was given. The dependent variable $\mathrm{y}$ is 1 for share contracts and zero otherwise. The logit model assumes that $y$ depends on an unobserved variable $y^{*}=a_{0}+a_{1} P B+$ $a_{2}$ POOR $+u$, where the $a_{i}$ are unknown coefficients, $u$ has a logistic distribution, $y=1$ if $y^{*}$ $>0$, and $y=0$ otherwise. We estimate the $a_{i}$ by maximum likelihood methods (they are given with t-statistics in the table), and we can use them much as we use regression coefficients. For example, a positive $a_{1}$ would imply that petty bourgeois landlords were more likely to lease land on shares (as Bloch maintains), while a negative $a_{1}$ would imply the reverse. The same would hold for $a_{2}$. But since our $a_{1}$ turns out to have a sign different from what Bloch suggested and since our $a_{2}$ turns out not to be significantly different from zero, the evidence belies Bloch's argument.

Source: Sample of 83 rental, share, and labor contracts from Archives départmentales du Rhône, 3 E 1028-30, 1058, 2208-09, 2192, 8721-23, 8731-32, 8740, 8779. The records involved were all notarial records from a tiny area south of Lyon, near the towns of Saint-Genis-Laval, Taluyers, and Givors. The contracts date from the period 1563-1633, when the growth of sharecropping was at its height.

during the declining prices of the 1600s. It spread in times of population growth and of population decline, and despite overall similarities in European population trends, sharecropping took root only in particular areas, such as parts of Italy and France. Finally, at least in France, the rise of sharecropping did not coincide with any major shift in seignorial dues or seignorial authority: the great dislocations in seignorial power occurred either in the later Middle Ages, well before sharecropping prevailed, or in the eighteenth century, well after it was firmly established. ${ }^{6}$

A much more successful explanation of sharecropping emerges from a consideration of the problems landlords faced. Perhaps the best contemporary discussion of these difficulties appears in Olivier de Serres's Théâtre de l'agriculture, the classic treatise of 1600 on French farming. For de Serres, the hardships that property owners encountered were legion. Chief among them was the task of managing and of overseeing farms, a matter to which de Serres devoted an entire chapter of his book. Ideally, de Serres argued, a landlord would work his own

\footnotetext{
${ }^{6}$ On the crisis of French seigniors, see Robert Brenner, "Agrarian Class Structure and Economic Development in Pre-Industrial Europe: The Agrarian Roots of European Capitalism," Past and Present, 97 (Nov. 1982), pp. 58-65, 76-83.
} 
land, hiring laborers and personally supervising their efforts. The drawback, though, was that farms and agricultural laborers required constant attention on the part of the owner. Only his supervision could "make the lazy diligent" and counter "the evil tendency of most hired hands, which in the absence of the master leads them merely to feign any effort." But the master's presence would cost him dearly if his property lay far from his home or if he had other affairs where he "earned much more than in the cultivation of the soil."

For absentee landlords of this sort, renting was the obvious alternative, either for fixed rent or for shares. But even renting entailed certain complications. It was hard to find a reliable tenant who, while paying a fixed rent, would remain solvent, shoulder all the work, and absorb "at his own loss or profit" all the risks of the farm year. Such a tenant would pay less rent in return for taking on all the risk, and he would demand an even greater reduction if he furnished all the seed, livestock, and other farm inputs. ${ }^{8}$ Given the difficulties of finding dependable tenants, de Serres recommended sharecropping for most absentee landlords. It would be easier to find a trustworthy share tenant, for he did not "risk everything in advance," and he was less likely to go bankrupt. Whatever the form of the lease, though, the landlord would still have to watch over the tenant. Even a fixed-rent tenant might neglect buildings and fences or ignore problems with ditches that might cause flooding or erosion long after his lease had run out. He might cut vines too short, which could boost the yield during his tenure but reduce productivity thereafter. And at the end of his tenure, he might return the land "tired and exhausted, like rental horses.",

One might dismiss de Serres as overly progressive and therefore unrepresentative of the majority of French landlords, but contracts in notarial registers testify to the same concerns. Labor contracts (such as the one concluded in 1598 between the notary Estienne Moyne of SaintGenis-Laval and two partners, on the one hand, and Pierre Dupyn and Nicolas Charpin of Saint-Genis, on the other) always specified the tasks the laborers were to perform. Dupyn and Charpin, for example, were told in great detail what they were to do in a local vineyard that Moyne and his partners managed, and they were paid in stages as the work progressed in order to keep them from shirking. Share contracts did much the same, since croppers also had reason to undersupply labor. As for rental contracts, they commonly obliged tenants to pledge other

\footnotetext{
${ }^{7}$ Olivier de Serres, Le théâtre de l'agriculture (Paris, 1600), pp. 45, 47-50; Bloch, History, p. 144.

${ }^{8}$ De Serres, Le théâtre, pp. 46-48, 53. For more contemporary evidence from Normandy on this point and on the costs of administering estates in general, see Jonathon Dewald, The Formation of a Provincial Nobility (Princeton, 1980), pp. 195-200.

${ }^{9}$ De Serres, Le théâtre, pp. 46-47, 53; Philip T. Hoffman, "Sharecropping and Investment in Agriculture in Early Modern France," this Journal, 42 (March 1982), 155-59.
} 
property as security against default. And whatever the contract, all farm owners tried to prohibit the misuse of property by tenants who might squander resources while avoiding the costs. It was not unusual to see prohibitions against the neglect of ditches and buildings, against the overworking of vines, excessive grazing or logging, and, in general, against the failure to return the property in good shape at the end of the lease. ${ }^{10}$

In a frictionless, one-period world of no risks and perfect information, such problems never arise. But in the real world, these problems do bedevil landlords, and under the heading of transaction costs, they form part of the modern theory of agricultural contracts, a subject that has attracted the attention of a number of economic theorists and economic historians. Although this theory of contracts is far from complete, it does at least provide an explanation for the coexistence of rental, share, and wage-labor contracts in agriculture, and it also accounts for variations in the contractual mix. ${ }^{11}$ In a nutshell, the theory is based upon a trade-off between the transaction costs associated with a given contract and the risk premium needed to get parties to enter that contract. The transaction costs, which fall upon landlords, include the

${ }^{10}$ Archives départmentales du Rhône (Lyon, France), 3 E 8731 (Nov. 5 and Dec. 3, 1598); 8732 (Feb. 7 and April 30, 1599; Jan. 6, Sept. 14, and Nov. 25, 1600); 8779 (April 4 and 9, 1600); 1028, fol. 133 (1576); 8721 (July 3, Dec. 4, and Dec. 17, 1570).

${ }^{11}$ For what follows, see David M. G. Newbery, "Risk, Sharing, Sharecropping and Uncertain Labor Markets," Review of Economic Studies, 44 (Oct. 1977), 585-94; Joseph Stiglitz, "Incentives and Risk Sharing in Sharecropping," Review of Economic Studies, 41 (April 1974), 219-55; David M. G. Newbery and Joseph Stiglitz, "Sharecropping, Risk Sharing and the Importance of Imperfect Information," in Risk, Uncertainty, and Agricultural Development, ed. James A. Roumasset and Jean-Marc Boussard (College Laguna, 1979), pp. 311-39; Peter G. Warr, "Share Contracts, Limited Information and Production Uncertainty," Australian Economic Papers, 17 (June 1978), 110-23; Robert E. B. Lucas, "Sharing, Monitoring, and Incentives: Marshallian Misallocation Reassessed," Journal of Political Economy, 87 (June 1979), 501-21; Robert Higgs, "Race, Tenure, and Resource Allocation in Southern Agriculture, 1910," this Journal, 33 (March 1973), 149-69; Lee J. Alston, "Tenure Choice in Southern Agriculture," Explorations in Economic History, 18 (July 1981), 211-32; Lee J. Alston and Robert Higgs, "Contractural Mix in Southern Agriculture Since the Civil War: Facts, Hypotheses, and Tests," this Journal, 42 (June 1982), 327-53. For additional work by economic theorists and economic historians on sharecropping, see Hoffman, "Sharecropping and Investment," pp. 155-56. There are of course a number of problems with this literature. To begin with, apart from several qualitative remarks, Newbery and Stiglitz deal with a world where the costs of monitoring labor are either zero or infinite-clearly unrealistic. If these monitoring costs are zero, they go on to show that sharecropping offers no risk-sharing advantages, provided there are no economies of scale and no uncertainty in factor markets; see Hoffman, "Sharecropping and Investment," pp. 155-56, for details. More realistic theory can be found in Warr and Lucas, who deal with sharecropping versus renting and sharecropping versus labor; both these articles include specifics of the effect of monitoring and transaction costs upon contractual choice. As for Higgs and Alston, they have the virtue of using a simple model involving a trade-off between transaction costs and the risk premium needed to attract tenants. Their work has been most useful, but they assume (as do I) that landlords enter into contracts after they have made decisions about what to farm. For the problems of such an assumption, see Alston, "Tenure is Southern Agriculture," p. 219. What we need is a general equilibrium model that explicitly includes transaction costs and explains the mix of all three types of contracts. Such a theory does not yet exist. 
costs of enforcing the contract and of insuring that the tenant or the hired hand meets his part of the bargain. The landlord's transaction costs are highest for labor contracts, for in addition to keeping the laborer from misusing the property, the landlord has to supervise him to make sure he furnishes the amount of labor specified in the contract. With perfect information and no uncertainty, a landlord could observe the hired hand's effort directly or infer it from agricultural output. But in the real world, he has to pay to discover how hard the laborer works, and he has to monitor him in order to prevent shirking. The transaction costs are somewhat lower for sharecropping, because the cropper has some incentive to work; however, the landlord must still supervise the cropper to a certain extent, because the cropper receives only a fraction of his marginal product and hence has reason to undersupply labor. Transaction costs are lowest of all for fixed-rent contracts, for the renter receives his full marginal product and therefore has no reason to shirk. The landlord need only insure that the tenant does not ruin the property. ${ }^{12}$

What keeps landlords from offering nothing but fixed rental contracts with their low transaction costs is the premium (in the form of reduced rent, for example), which they must offer risk-averse tenants in order to induce them to accept the uncertainties of paying a fixed rent. The premium is lower for share contracts because croppers absorb only a fraction of the risk. And since there is little or no risk attached to a fixed wage payment, the landlord need offer no premium in order to engage farmhands. The mix of contracts is then determined by the balance between transaction costs and risk premiums.

If transaction costs increase (other things being equal) then we would expect landlords to shift from wage contracts toward sharecropping and renting. Rental contracts would also become preferable to share agreements. In each case, more landlords would prefer to pay risk premiums to tenants rather than to face the higher transaction costs, and the resultant change in the supply of contracts would shift the contractual mix. And of course the reverse would be true if transaction costs dropped.

One virtue of this theory is that it clearly fits the qualitative evidence from early modern France. De Serres and other contemporaries noticed that renters demanded a premium in the form of lower rent for the risks

\footnotetext{
12 This account of contract choice is only one among several possible theories; there are other explanations that place greater stress upon the landlord's entrepreneurial input, other factors of production, and incentives. See, for example, William Hallaghan, "Self Selection by Contractural Choice and the Theory of Sharecropping," Bell Journal of Economics, 9 (Autumn 1978), 344-54; and Joseph D. Reid, "Sharecropping and Agricultural Uncertainty," Economic Development and Cultural Change, 24 (April 1976), 549-76. These alternative theories, though, have their own limitations-Reid, for example, tends to glide over questions of monitoring costs-and they do not fit the early modern qualitative evidence as well as the explanation I have given. In any case, all of these different theories are in fact more complementary than mutually exclusive.
} 
they faced, and de Serres suggested that the premium and the risks were reduced for sharecroppers. De Serres and the contracts themselves also make it clear that landlords had to do more and more monitoring as they moved from renting toward sharecropping and wage labor. Indeed, rental contracts invariably contained fewer stipulations than either share or wage labor contracts.

Furthermore, the theory actually yields a hypothesis applicable to early modern quantitative data: if transaction costs rise, a given landlord will be more likely to prefer rental contracts to sharecropping, and sharecropping to wage labor, all other things being equal. We can then test this hypothesis with the Lyonnais contracts that we used to examine Bloch's ideas. The transaction costs themselves are unobservable, but the contracts do furnish two useful proxies for the costs of supervising a farm and of monitoring labor. The first is the distance between the landlord's residence and the location of his property. De Serres and other contemporaries noted that distant property was more expensive to administer, and for this reason de Serres all but ruled out wage labor for most absentee landlords. ${ }^{13}$ Obviously, transaction costs would rise the farther away the property.

The second proxy affecting transaction costs is the presence or absence of vineyards. Vines were a capital investment requiring considerable supervision whatever the contract-recall, for example, de Serres's warning against tenants who cut them too short. Once the landlord took steps to inspect the vines, though, the marginal cost of monitoring his sharecropper's or his hired hand's labor was reduced. On farms with vines, then, we would expect lower costs for monitoring labor, more sharecropping relative to renting, and more wage labor relative to any form of tenancy. ${ }^{14}$

The evidence from the sample of Lyonnais contracts supports both these contentions. In the tiny region from which these contracts were drawn, risks probably did not vary greatly; hence we can in effect hold constant the other major factor-risk conditions-which affected the contractual mix. ${ }^{15}$ Transaction costs should then explain the variations in contract type, and if we apply logit analysis, we find that our proxies for the transaction costs do indeed have the expected effect on contract choice (Table 2). The positive sign of the distance variable coefficients implies that landlords were more likely to lease distant property to renters and sharecroppers than to hire wage labor. Distant estates were also more likely to be leased for a fixed rent than sharecropped. Similarly, the negative coefficients for vines suggest that vineyard owners were more likely (other things being equal) to hire laborers than

\footnotetext{
${ }^{13}$ De Serres, Le théâtre, pp. 46-48, 53. See also Dewald, Formation of a Provincial Nobility, pp. 183-201.

${ }^{14}$ Compare the similar argument of Alston and Higgs, "Contractual Mix," p. 340.

${ }^{15}$ Compare ibid., p. 344.
} 
TABLE 2

LOGIT ANALYSIS OF CONTRACT CHOICE

\begin{tabular}{lcc}
\hline \multicolumn{1}{c}{ Variable } & $\begin{array}{c}\text { Coefficient for Effect on } \\
\text { Renting Relative to Wage } \\
\text { Labor }\end{array}$ & $\begin{array}{c}\text { Coefficient for } \\
\text { Effect on } \\
\text { Sharecropping } \\
\text { Relative to } \\
\text { Wage Labor }\end{array}$ \\
\hline Constant & 1.932 & 1.869 \\
VINE (1 for Property with & -4.45 & -3.25 \\
$\quad$ Vineyards, zero otherwise) & -3.15 & -2.38 \\
t-statistic & 0.076 & 0.060 \\
DISTANCE (Kilometers from & & 1.65 \\
$\quad$ Landlord's Home to & 2.07 & \\
$\quad$ Property) & 83 cases & \\
t-statistic & $58.47(6$ degrees of freedom) \\
N & Log-likelihood ratio &
\end{tabular}

Note: The logit analysis seeks to explain the choice of rental, share, or labor contracts by means of the two independent variables: VINE and DISTANCE. As in the simple case of binomial logit, we assume that choice of contract is dictated by unobserved latent variables that are linear functions of VINE and DISTANCE. If $P_{1}, P_{2}$, and $P_{3}$ are the probabilities, respectively, of rental, share, and labor contracts, then it turns out that

$$
\ln \frac{P_{1}}{P_{3}}=a_{0}+a_{1} \text { VINE }+a_{2} \text { DISTANCE, }
$$

where $a_{0}, a_{1}$, and $a_{2}$ are the coefficients estimated in the left column above. Similarly,

$$
\ln \frac{P_{2}}{P_{3}}=b_{0}+b_{1} \text { VINE }+b_{2} \text { DISTANCE, }
$$

where the $b_{i}$ are estimated in the right column above. Again, we can interpret the coefficients much as we do in regression: the positive coefficient of DISTANCE in the right column implies that the greater the distance, the more common sharecropping is relative to wage labor. Note that we can also estimate the relative odds of rental versus sharecropping; it follows from the relationships and estimates above that

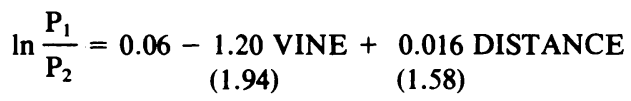

Here t-statistics are in parentheses. Note that vines make sharecropping preferable to renting, and distance does the reverse.

Source: See Table 1 .

to engage tenants. They also found sharecropping preferable to renting, as expected. Furthermore, not only did all of these coefficients have the proper signs, but nearly all of them passed the appropriate one-tailed tests of significance at better than the 5 percent level. ${ }^{16}$

Obviously, a number of criticisms could be raised against this evidence. First, one could argue that instead of using the presence of vines as a proxy for lower labor-monitoring costs we should have included any landlord contribution of capital. Any capital good or equipment, from vines and oxen to hand tools, would cut the marginal

\footnotetext{
${ }^{16}$ One-tailed tests are appropriate since the theory predicted the signs of the various coefficients.
} 
cost of supervising labor. This is certainly a reasonable argument, and the only justification for singling out vines is that they were mentioned by de Serres and that they represented the landlord's major capital contribution to local farming. They also undoubtedly required more supervision than other capital goods. In any event, substituting the presence of any landlord capital does not change the logit analysis significantly. All the coefficients still have the proper sign, and most are still significant. ${ }^{17}$

A second concern might be a number of additional variables that perhaps should be included in the analysis. Higher urban wages, for example, could conceivably make agricultural labor contracts harder to enforce, because a hired hand might abandon the plow to work in town. But if we insert a real wage index for urban workers into the logit analysis, it fails the significance test, no doubt because the labor market was strong enough to provide a replacement for any farm worker who quit his post. ${ }^{18} \mathrm{~A}$ more troubling omission is the lack of any measure for the amount of land being farmed. A large farm might well involve increased labor supervision costs, and thus farm size might affect the choice of a contract. Unfortunately, the agricultural contracts from this period do not usually report the size of the plots in question, so no perfectly reliable land measure is available. But we can take refuge behind the fact that in those contracts that do mention land size the farms are relatively homogeneous. Moreover, we can use the number of plots mentioned in each contract as a crude measure of farm size; when added to the logit analysis, the number of plots fails significance tests and does not disturb the other coefficients. ${ }^{19}$

Finally, one might criticize the assumption that risk conditions remained constant. While agricultural risks might not have varied greatly over the tiny region from which the sample was selected, they could have changed over the period the contracts covered (the years 1563-1633), and the fluctuations in risk might have affected the contract mix. One way to test this would be to employ the variations in local lease rates as an approximate measure of risk. When inserted into the logit analysis, though, this risk proxy proves insignificant, and it hardly

${ }^{17}$ The presence of vines does seem to have a stronger effect on contract choice than do other sorts of landlord capital. The reason may be that the vineyards required more constant surveillance than tools or animals; moreover, damage to vines was more difficult to remedy since there was obviously no rental market one could turn to in order to replace damaged vines.

${ }^{18}$ If we add a real wage index for urban building workers to the logit equations with VINE and DISTANCE, the $t$-statistics are far from significant $(t=0.22$ for the effect on renting; $t=-0.05$ for the effect on sharecropping). I have also tried to add various human capital measures, such as literacy and occupation, to the logit analysis, because some of the literature on contract choice suggests that the various contracts allow landlords to screen for tenant skill. Unfortunately, I found no evidence for this, no doubt because my human capital proxies were poor measures of the requisite skills.

${ }^{19}$ With a larger sample, we could verify that the number of plots was an accurate proxy by checking it for those contracts that do mention farm size. I plan to do this in future research. 
affects the other logit coefficients. ${ }^{20}$ Evidently, risk conditions did not vary enough to shift contract choices.

To be sure, a sample of 83 cases may seem like very little evidence to hinge a theory upon, but the $t$-statistics belie the insinuation that the results are the work of chance. More evidence and more analysis are certainly in order before we can be certain (one would like to know, for example, what risks peasants faced as consumers, what other forms of insurance were available to them, and what bigger landlords did), but at the very least the theory of agricultural contracts gives us an attractive candidate for future research. ${ }^{21}$ And as we have seen, the theory has the added virtue of explaining the qualitative evidence, drawn from de Serres and other sources in several regions of early modern France.

The theory also provides a ready explanation for the spread of sharecropping. Sharecropping, we saw, grew more prevalent at precisely the same time that French peasants were losing their land to absentee landlords. These absentee owners had to contend with costs of administering distant, newly purchased properties, and from what we know of the theory of contracts, it was only natural that they resorted to sharecropping (and to renting) instead of hiring laborers. ${ }^{22}$ The increase in sharecropping (relative to wage labor) was thus a result of the transfer of peasant property into the hands of absentee landlords, and this transfer itself appears to have been caused by the monarchy's fiscal system, for the monarchy was granting increasingly valuable tax exemptions to precisely the sort of privileged person who bought up the peasant land. These nobles, officers, and city dwellers paid little or nothing in the way of taxes on the peasant land they purchased, and they bought up land from tax-paying peasant proprietors until the costs of administering distant property outweighed the value of their tax exemptions. ${ }^{23}$ As absentee owners, they simply found sharecropping preferable to wage labor.

It is clear as well why sharecropping was so often associated with poverty: it was, quite simply, a way of administering property in areas

\footnotetext{
${ }^{20}$ I relied upon an index of lease rates for a fixed collection of farm plots to construct my risk proxy. If the lease rates included a risk premium, then the level of the index itself ought to provide a rough proxy of risk conditions. If, on the other hand, the lease rates reflected only the expected profits from farming, then the coefficient of variation of the lease rates ought to track risk. I tried both proxies for risk, with similar results.

${ }^{21}$ One additional task for future research is to specify a theoretical model in such a way that under certain circumstances sharecropping could actually become preferable to both wage labor and renting. This would be possible, for example, with a probit model.

${ }^{22}$ A numerical example would be useful here. On the basis of our logit coefficients, we would expect a landlord who lived adjacent to his vineyard to sharecrop only 19 percent of the time and employ wage labor 75 percent of the time. An absentee landlord who lived 20 kilometers from the vineyard (a typical figure in the Lyonnais) would be much more likely to sharecrop (38 percent of the time) and less likely to farm with laborers (45 percent of the time).

${ }^{23}$ For this, see "Social History and Taxes: The Case of Early Modern France," California Institute of Technology Social Science Working Paper 495 (1983).
} 
where overburdened peasants had lost their farms to absentee owners, a contract undertaken with tenants who possessed little or no land or capital. But if sharecropping was associated with rural poverty, it is wrong to blame it for France's agricultural stagnation. The frequent claim that sharecropping meant disengagement from the market collapses once we realize that highly commercial crops were often raised by croppers: not just wine in the Lyonnais, but also mulberry trees for the silk trade farther south. Indeed, share landlords were frequently involved in the sale, rather than in the consumption, of the produce from these estates. ${ }^{24}$ Nor does it seem proper to argue that the draconian clauses in sharecropping leases stifled agricultural change. These clauses, we have seen, were merely rational attempts to protect property rights and monitor labor. They were supple enough to change from place to place and over time, and regular labor contracts contained even more rigid clauses. ${ }^{25}$ Indeed, economic theory suggests that sharecropping was merely a way of dealing with risk, incentives, and transaction costs. It was thus not an obstacle to economic growth, and the true causes of agriculture stagnation in France have to be sought elsewhere-perhaps in the tax system that treated peasants so unfairly.

\footnotetext{
${ }^{24}$ Duby et al., Histoire, vol. 2, p. 235; Serge Dontenwill, "Les baux à mi-fruits en Roannais et Brionnais aux XVIIe et XVIIIe siècles," in Jean-Pierre Gutton, Lyon et l'Europe: Hommes et Sociétés: Mélanges d'histoire offerts à Richard Gascon, 2 vols. (Lyon, 1980), vol. 2, p. 198.

${ }^{25}$ Although Louis Merle talks of the "draconian" terms of the sharecropping contracts, he acknowledges that they changed; see Merle, La métairie, pp. 161-85, 203, and also de Serres, Le théâtre, pp. 51-52.
} 